www.czasopisma.marszalek.com.pl/pl/10-15804/npw

\author{
Aleksandra Bartosiewicz \\ University of Lodz \\ ORCID ID: https://orcid.org/0000-0002-6464-9277 \\ Paulina SzTERLIK \\ University of Lodz \\ ORCID ID: https://orcid.org/0000-0003-1792-4691
}

\title{
New Silk Road - An Opportunity for the Development of Rail Container Transport in Poland?
}

\section{New Silk Road - An Opportunity for the Development of Rail Container Transport in Poland?}

\section{Abstract}

Poland, due to its location in the center of Europe, is a key element of the New Silk Road (NSR), an initiative that attempts to create the shortest land connection between China and Western Europe. This article analyzes various industry reports, national development strategies up to 2030, and EU and local projects to see is the further development of NSR an opportunity for container rail transport in Poland. As it turns out, the issue discussed in the article has hitherto been outside the circle of researchers' interest, thus the analysis is an important supplement to the existing research gap. It indicates that the further participation of Poland in the Chinese One Belt One Road initiative is a great opportunity for the economic growth of the Republic of Poland (RP).

Keywords: Polish-Chinese relations, One Belt One Road, New Silk Road, rail transport, container transport 


\section{Новый шёлковый путь - шанс для железнодорожного контейнерного транспорта в Польше?}

\section{Аннотация}

Благодаря своему расположению в центре Европы Польша - ключевой элемент китайской инициативы, которая является попыткой создать самое короткое сухопутное соединение между Китаем и Западной Европой. В данной статье были проанализированы различные типы отраслевых отчетов, национальные стратегии развития до 2030 года, а также проекты Один пояс и один путь и местные проекты для того, чтобы ответить на вопрос, является ли дальнейшее развитие Нового шёлкового пути шансом для железнодорожного транспорта в Польше. Оказывается, что представленная в статье проблема до сих пор остается вне круга интересов исследователей данной темы и проведенный анализ частично заполняет существующий пробел в исследованиях. Проведенный анализ показывает, что дальнейшее участие Польши в китайской инициативе Один пояс и один путь создаёт чудесные возможности для экономического роста Республики Польша.

Ключевъе слова: Польско-китайские отношения, Один пояс и один путь, Новый шёлковый путь, железнодорожный транспорт, контейнерные перевозки

\section{Introduction}

For over a dozen years, the Republic of Poland (RP) has been striving to maintain good relations with the People's Republic of China (PRC), recognizing political dialogue as a basic condition for further strengthening of the economic cooperation between the countries. In 2013, when the New Silk Road (NSR) became the most important issue in the foreign policy of China, Poland immediately decided to participate in the new Chinese undertaking. The hypothesis presented in the article states that the NSR is an opportunity for a further and more dynamic development of railway connections in Poland. It was later verified by analyzing documents and publications on mutual Sino-Polish relations, in particular data published in various industry reports, national development strategies until 2030 or European Union (EU) and local projects. The information collected in that way were then used to fill the existing research gap regarding the NSR initiative. As far as literature is concerned, the Sino-Polish relations have been described only in a few publications (Bartosiewicz, Szterlik, 2018; 2019; Bentyn, 2016; Górski, 2016; 
2017; Kamiński, 2019; Lubina, 2017; Marszałek-Kawa, 2014; Marszałek-Kawa, Dmochowski, 2018; Motowidlak, Kujawa, 2018; Szczudlik-Tatar, 2015; 2016), none of which refers to the impact of the Chinese initiative on container rail transport in Poland.

\section{Strategic Relations between Poland and China after 1989}

Dynamic internal transformations within Poland and China are the main reasons for the negligence of the correctness of Sino-Polish diplomatic relations at the beginning of 1990s. The political dialogue was renewed in 1991, due to mutual visits of the Ministers of Foreign Affairs, Krzysztof Skubiszewski and Qian Qichen. In 1993, an exchange of visits between Henryk Goszewski and Zou Jiahua, the then prime ministers of the RP and the PRC, resulted in the creation of an agreement on the long-term appearance of economic and trade relations between the countries (Embassy of the RP, 2018). Then, during the visit of the Polish President Aleksander Kwaśniewski to China in 1997, the first visit of the head of the Polish state in the PRC in over thirty-eight years, 'The Joint Communique of the People's Republic of China and the Republic of Poland' (1997) was signed. In 2004, in turn, another high-level bilateral meeting ended with the publication of 'The Common Statement between the Republic of Poland and the People's Republic of China' signed by Kwaśniewski and Hu Jintao. Both documents have constituted a general record of the framework and the principles for the development of relations between the PRC and Poland.

In 2008, a visit of Dalai Lama in Poland, due to the tension between China and Tibet, was deeply disapproved by the Chinese government. The event did not, however, deteriorate relations between the countries. A real breakthrough in the Sino-Polish relations seemed to be, however, the EXPO 2010 exhibition with the Polish Pavilion placed in a central, well-exposed part of the exhibition square (Tuszyński, 2014). Yet, in the following years steps have been taken to further improve Sino-Polish relations. For example, the visit of President Bronisław Komorowski in Beijing (2011) was concluded with the signing of 'The Joint Statement of the Republic of Poland and the People's Republic of China' regarding the establishment of strategic partnership. The agreement was established in order to raise the rank of 
cooperation between the two countries in the most important spheres of interstate relations (Sino-Polish, 2011). In 2012 the cooperation of 16 countries of Central and Eastern Europe with China was inaugurated in the so-called $16+1$ format. Poland was included in the plan. Simultaneously the "Go China” programme was launched as an initiative of the Polish Ministry of Economy which supports Poland's economic cooperation with the PRC. Since the 2015 elections, the United Right, Polish right-wing conservative alliance, has been in power. It oriented its foreign policy in favor of the US and fell into conflict with the EU. Poland has, as a result, become a less attractive partner for the China, which is an active competitor of the United States and seeks approval from the EU.

Furthermore, even though in 2016 the level of mutual relations between Poland and the PRC was raised to a comprehensive strategic partnership and in March 2019 the $6^{\text {th }}$ round of dialogue on bilateral relations and cooperation mechanisms between the two countries took place, the Polish government has in recent times developed no political strategy toward the PRC (Lasoń, 2018). This is reflected in the text of the Polish Foreign Policy Strategy for 2017-2021 in which it was only stated that Poland should seek cooperation with non-European partners, especially the PRC. The partnership should be based on the implementation of various infrastructure projects, including those which are a part of the BRI (MSZ,2016). At the same time, the weakening of interstate relations in 2017 reduced the involvement of Polish regional authorities in establishing economic cooperation with Chinese partners. For example, since 2016 the subsequent Poland-China Regions Forum could not be organized, which is partly due to the difficulties in agreement between the authorities of both countries regarding the programme and forum participants which next edition should take place in China (Skorupska, Szczudlik, 2019).

\section{The International Expansion of the People's Republic of China}

The dynamism of changes in global trade and the desire to invest in foreign markets have prompted the Chinese government to create a strategy of international expansion. An important element of the new Chinese global order, sometimes referred to as the Silk Global Order, is the BRI (Sulmicki, 
2018). In 1999, the Going Global plan (also known as the Go Out Policy) was initiated. Its main goal was to motivate Chinese enterprises to invest abroad. The first phase of the plan, i.e. Going Global 1.0, started in 2001 with the admission of the PRC to the World Trade Organization (WTO). It was developed during the so-called $\mathrm{Hu}$-Wen New Administration, which refers to the period of the leadership of president $\mathrm{Hu}$ Jintao and prime minister Wen Jiabao (2002-2012). These were the times when the Chinese government tried to improve the global image of the PRC by creating various soft-power strategies, such as the peaceful growth (2003) as well as peaceful development (2004), both deeply rooted in the principles of Confucianism. The strategies were supposed to stand in opposition to American hegemony and to alleviate global concerns related to the intensification of China's actions in the international arena (Walkowski, 2017). The first phase of global expansion was focused on (Luo, 2018):

- gaining control over the natural resources;

- taking over complete value chains and attempting to recreate their mechanisms in China;

- becoming majority shareholders in foreign enterprises;

- searching for local political support.

Using business models borrowed from foreign companies was difficult for Chinese investors. The inhibition of global demand and the internal problems of the PRC, related mainly to corruption, turned out to be disadvantageous. The remedy for the problems encountered during the first phase of the strategy was to constitute the initiative's entry into the promoted by the $\mathrm{Xi}$ Jinping' government Going Global 2.0 phase. It is supposed to facilitate the restructuration of the Chinese economy by stimulating demand from the other member states of the Organization for Economic Cooperation and Development (OECD). Numerous projects related to the Chinese industry, such as Made in China 2025, also aim to promote an economy based on building a technological advantage and promoting innovation (China Policy, 2017). 


\section{The importance of the New Silk Road for Poland}

In $2013 \mathrm{Xi}$ Jingping, the President of the PRC, expressed a desire to initiate the One Belt One Road initiative (OBOR), which was to be a direct reference to the historical Silk Road, a network of connections between China, Europe and the Middle East. The main assumptions of the initiative can be described as (Łopacińska, 2017):

- the willingness of the PRC to increase the number of investments in the countries participating in the initiative;

- supporting trade between the member countries;

- giving support to investments in infrastructure;

- undertaking activities related to increasing the efficiency of transportation.

Political destabilization in the Middle East (the so-called Arab Spring) and insecure internal situation in the Ukraine made it clear that from the PRC's point of view the safest land connection between China and Europe would be the route running through Kazakhstan, Belarus and Poland (the New Eurasian Land Bridge - NELB economic corridor). The fact that China is a major trading partner of Poland, especially considering the import of goods, is of significant importance too. Textile products, footwear, electronic equipment and household appliances are often imported from the PRC, as well as advertising gadgets, interior and garden furnishings or the printing equipment (CSO, 2017). Approx. 90 percent of those products are delivered exclusively to satisfy the demand of the Polish customers, while the remainder is transported to the other countries of the EU. From the point of view of Polish exporters, a particularly important tendency can be observed recently, which is the growing interest of Chinese consumers in imported food. The trade of imported food products in the PRC from 2005 to 2014 has more than quadrupled (CWGP-PRC, 2015). The latest reports of the Polish Investment and Trade Agency (PITA) states, that Polish healthy foods (apples, juices, mineral water, confectionery and dairy products), cosmetics, jewellery, furniture, as well as medical devices and parts of motor vehicles have a particularly good chance of success in China (Polskie firmy, 2018).

Poland is also a key element of the NSR due to its favorable geographical location. In 2016, President Xi Jingping, who was visiting Warsaw, highlighted 
that economic and commercial cooperation between China and Poland is a priority issue, resulting from the fact that the countries are located on the two sides of the Eurasian bridge (Przywódcy, 2016). The speech emphasized the fact that Poland is the country on which the NSR and the Amber Road intersect and that it is included on the China Railway Express Route (Jingping, 2016).

Moreover, the argument in favor of locating in Poland the main European logistics centres servicing goods transported along the NSR is the fact that the most important economic corridors for international rail transport, covered by the European Agreement on Main International Railway Lines (AGC), as well as those which are mentioned in the Contract on Important International Combined Transport Lines (AGTC), pass through the territory of the RP, which is also a part of two out of the nine corridors of the Trans-European Transport Network (TEN-T), that is the Baltic-Adriatic corridor and the North Sea-Baltic Sea corridor (Bartosiewicz, Szterlik, 2018).

Actions to create a common transport corridor between the Baltic Sea Region (BSR) (Świnoujście, Szczecin, Gdynia, Gdańsk) and the Northern

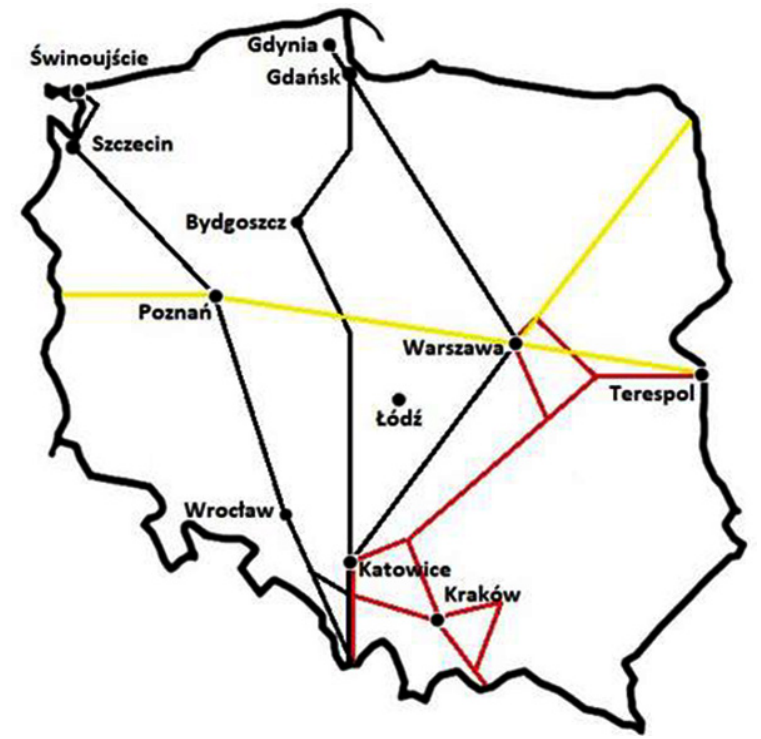

Figure 1. The route of the Baltic-Adriatic corridor (black), the North Sea-Baltic Sea corridor (yellow) and the Amber Corridor (red) through Poland Source: own elaboration. 
Adriatic ports (Koper, Trieste, Venice, Ravenna) were undertaken in 2014. The route runs through Poland on the axis of the A1 motorway and the E-65 and C-E65 railway lines. Additionally, it takes the course of the E-59 railway line and some sections of expressways.

The Baltic Sea-North Sea transport corridor, in turn, runs on the axis of the E-75 railway line, the Via Baltica road as well as on the axis of the A2 motorway, the E-20 and C-E20 railway lines. Finally, the so-called Amber Road Freight Corridor (ARFC) includes ports located in South-Eastern Europe (Piraeus, Bar, Kopra), while by 2026 the final route for transporting Polish goods to the South is to be the Podłęże-Szczyrzyc-Tymbark/Mszana Dolna railway connection, leading to the Muszyna-Plavec railway border crossing (Engelhardt, 2014).

\section{Rail Infrastructure in Poland}

The dynamic development of transport corridors forces investments in infrastructure elements supporting logistic processes (Tab. 1). The analysis of the plans related to the expansion of the NSR allows to conclude that the Chinese side sees this type of investment as one of the main tools for the construction of the BRI. As it turns out, the railway network in Poland still requires significant investments in order to eliminate bottlenecks and adaptation to technical requirements, especially regarding the railway lines in cross-border traffic (track gauge, electrification degree, line capacity, maximum permissible speed, etc.) specified in Regulation No. 1315/2013 of the European Parliament and the Council of 11 December 2013 (Regulation, 2013). As a result, for railway transport priority was assigned to further improvement of the technical parameters of railway lines, including in particular (MTBiGM, 2012):

- consistent modernization and revitalization of the existing railway line network, so that in 2030 the major part of the network would be in better condition, and that it would be possible for the trains to run a technical speed of at least $100 \mathrm{~km} / \mathrm{h}$ on the lines of the TEN-T network;

- modernization and construction of terminals adapted to support intermodal container transport; 
- making a decision on the possible construction of a high speed rail system supplemented by the so-called ' $\mathrm{Y}$ ' by 2020 ;

- gradual implementation of the European Rail Traffic Management System (ERTMS) on the most important railway routes;

- modernization of the infrastructure of railway stations and stops;

- replacement of obsolete locomotives and wagons with modern rolling stock, corresponding to the specificity of individual market segments;

- undertaking actions aimed at better integration of rail and road transport.

Table 1. Basic railway projects connected to the freight corridors

\begin{tabular}{|c|c|}
\hline Project & $\begin{array}{c}\text { Years of } \\
\text { implementation }\end{array}$ \\
\hline $\begin{array}{l}\text { Perimeter line in Warsaw (sections: Warszawa Gołąbki/Warszawa Zachod- } \\
\text { nia-Warszawa Gdańska) }\end{array}$ & $2015-2018$ \\
\hline $\begin{array}{l}\text { Railway line No. } 93 \text { on the Trzebinia-Oświęcim-Czechowice Dziedzice } \\
\text { section }\end{array}$ & $2016-2020$ \\
\hline $\begin{array}{l}\text { E-20 railway line on the Warszawa-Poznan section; other works: the } \\
\text { Sochaczew-Swarzędz section }\end{array}$ & $2016-2020$ \\
\hline E-30 railway line on the Kędzierzyn Koźle-Opole Zachodnie section & $2016-2020$ \\
\hline $\begin{array}{l}\text { E-75 line on the Sadowne-Białystok section; other works: the Warszawa } \\
\text { Rembertów-Sadowne section (the Mazovian voivodship) }\end{array}$ & $2017-2018$ \\
\hline $\begin{array}{l}\text { C-E65 railway line on the Chorzów Batory-Tarnowskie Góry-Karsznice- } \\
\text { Inowrocław-Bydgoszcz-Maksymilianowo section }\end{array}$ & $2017-2020$ \\
\hline $\begin{array}{l}\text { Railway lines No. 132, 138, 147, 161, 180, 654, 655, 657, 658, } 699 \text { on the } \\
\text { Gliwice-Bytom-Chorzów Stary-Mysłowice Brzezinka-Oświęcim and } \\
\text { Dorota-Mysłowice Brzezinka section }\end{array}$ & $2017-2020$ \\
\hline Railway line No. 146 on the Wyczerpy-Chorzew Siemkowice section & $2017-2020$ \\
\hline Railway line No. 1 on the Częstochowa-Zawiercie section & $2017-2020$ \\
\hline $\begin{array}{l}\text { Alternative transport route Bydgoszcz-Trójmiasto, covering lines } 201 \text { and } \\
203 \text {, the } 1^{\text {st }} \text { and the } 2^{\text {nd }} \text { phase of the investment with the addition of the } \\
\text { electrification }\end{array}$ & $2017-2020$ \\
\hline $\begin{array}{l}\text { Improvement of the capacity of the E- } 20 \text { railway line on the Warszawa- } \\
\text { Kutno section, phase 1: the railway line No } 3 \text { on the Warszawa-border of } \\
\text { the LCS Lowicz section }\end{array}$ & $2017-2020$ \\
\hline $\begin{array}{l}\text { Railway lines No. 14, } 811 \text { on the Łódź Kaliska-Zduńska Wola-Ostrów } \\
\text { Wlkp. section, phase I: Łódź Kaliska-Zduńska Wola }\end{array}$ & $2017-2020$ \\
\hline
\end{tabular}




\begin{tabular}{|l|c|}
\hline Project & $\begin{array}{c}\text { Years of } \\
\text { implementation }\end{array}$ \\
\hline $\begin{array}{l}\text { Basic passenger routes (E-30 and E-65) in the area of Silesia, phase I: line } \\
\text { E-65 on the Będzin-Katowice-Tychy-Czechowice Dziedzice-Zebrzydo- } \\
\text { wice section }\end{array}$ & $2017-2023$ \\
\hline $\begin{array}{l}\text { E-75 line on the Sadowne-Białystok section; other works: the Warszawa } \\
\text { Rembertów-Sadowne section (the Podlasie voivodship) }\end{array}$ & $2018-2020$ \\
\hline $\begin{array}{l}\text { Railway line No } 6 \text { on the Białystok-Sokółka-Kuźnica Białostocka section } \\
\text { (the Polish border) }\end{array}$ & $2018-2021$ \\
\hline $\begin{array}{l}\text { C-E59 railway line on the Wrocław Brochów/Grabiszyn-Głogów-Zielona } \\
\text { Góra-Rzepin-Szczecin Podjuchy section }\end{array}$ & $2018-2022$ \\
\hline
\end{tabular}

Source: PKP, 2015.

Considering the railway accessibility of Polish regions to the 'core of Europe', the regions of the eastern and partly northern parts of the country are characterized by the highest peripherality, while the highest availability is characteristic of regions adjacent to the border with Germany and the Czech Republic (ESPON, 2018). In addition, despite the extensive spatial layout and relatively good parameters of the technical speed of Polish railways, metropolises are not conveniently connected with each other as a result of infrastructural and rolling stock restrictions, the most important of which are (MTBiGM, 2012):

- high percentage of tracks laid on wooden sleepers, which in large part exceeded the nominal period of use;

- non-adjustment of track systems at stations to current needs;

- poor technical condition of turnouts, as well as engineering facilities and traffic control;

- lack of safe driving control systems, which would allow trains to travel at speed exceeding $160 \mathrm{~km} / \mathrm{h}$;

- small number of crossings equipped with active safeguards;

- insufficient number of multi-level intersections with vehicular roads;

- limited capacity on some sections of the existing railway network.

More over, according to the analyses of the Polish Office of Rail Transport (ORT, 2018), the average density of intermodal terminals in Poland, in relation to the overall area of the country is much lower than in countries with the largest share of intermodal transport in the rail market (the Netherlands, Belgium, Germany). In 2017, there were 30 active terminals 
for intermodal transport in Poland, 24 of which were land terminals serving shipments in a rail-road relation. The best accessibility to the terminals was the characteristic of the Sląskie province and the regions around the largest agglomerations (Poznań, Warsaw, Wrocław, Łódź and the Tri-City), as well as the area between Upper Silesia and Łódź. The weakest accessibility was found in North-Eastern Poland, Central Pomerania, Kuyavian-Pomeranian province, South-Western part of Poland, including Żary and Żagań, as well as five large cities of over 100,000 residents (Bydgoszcz, Toruń, Białystok, Olsztyn and Koszalin) (Bocheński, 2017). The research, referring to the directions and intensity of cargo flow throughout the country, indicates that the existing network of intermodal terminals should be increased by approx. 20 new terminals and 6-8 regional logistic centres. The amount of specialized rolling stock should also increase, especially with regard to wagons for transporting semi-trailers, as well as those equipped with revolving frames, low-floor wagons or platforms designed for transporting various types of containers (MTBiGM, 2012).

\section{Impact of the New Silk Road on Container Rail Transport in Poland}

At the beginning of 2019, there were five large railway container transport operators in Poland operating on the route between Poland and China: Zhengzhou International Hub (ZIH), Hatrans Logistics, Fast East Land Bridge (FELB), Symlog and PKP Cargo SA (Operatorzy, 2019). The most important points on the Polish section of the NSR so far has been Małaszewicze, Warsaw, Łódź and Poznań, while in Łódź and Małaszewicze there are two key intermodal terminals to which Chinese containers are transported. There are plans of creating another terminal, located in Sławków, which would be able to serve up to a thousand trains annually. In November 2018, the PKP LHS signed a container transport agreement with the PRC regarding the Chengdu-Sławków route. During the meeting of the committee managing the International Trans-Passenger Transport Route (TMTM) corridor, held on January15-17, 2019 in Baku, the countries managed to establish common freight rates and the travel time of the container trains (Inicjatywa, 2019). 
In the context of trade between Poland and the PRC, it becomes important to create permanent rail connections, enabling regular import and export of goods. One of them is the Łódź-Chengdu connection, which has been in constant development since 2013, on the China-Kazakhstan-Russia-Belarus-Poland route, connecting the third largest city in Poland with the capital of Chinese Sichuan. As a result of the growing flows of containers arriving from China to Łódź, Hatrans, which manages the Łódź terminal, plans further expansion and, if possible, the construction of another container terminal in cooperation with partners from China, which would be dedicated only to handling cargo in relations with the PRC (Czubiński, 2019).

The cooperation of the city authorities with Chinese representatives so far has helped to change the capital of the Łódź region into a large European transhipment centre. New multimodal terminals have been created or expanded, and the process of railway infrastructure modernization has been constant. As a result, a new industrial district is being built in the Łódź Olechów area (Sa tereny, 2017) which is located near the Spedcont terminal, $4 \mathrm{~km}$ away from the A1 motorway exit, $17 \mathrm{~km}$ from the Łódź airport and only $30 \mathrm{~km}$ from the Łódź Północ junction (intersection of A1 and A2 motorways). In 2018, the BSH Hausgeräte GmbH completed the construction of a new logistics centre covering an area of 79 thousand sq. metres with two railway sidings which will be connected to the Łódź Olechów railway station. According to the investor's announcement, approx. 30 percent of cargo will be transported by rail (Czubiński, 2017b). The facility was built on the territory of Poland's largest distribution centre, Central European Logistics Hub managed by Panattoni Europe. Next to the BSH hall, further logistics centres will soon open, including the ones managed by Media Expert, Whirlpool, Smyk or Compin. In the near future, Panattoni Europe intends to buy nearby plots to obtain 1 million sq. metres of space. Up to 7,000 jobs are to be created in the complex until 2023 (Janocha, 2018; Jaroń, 2018). Moreover, in 2018, new investments were created not only in Łódź itself, but also in the entire province. In April, among others, the construction of one out of four parts of Zalando logistics centre in Głuchów ended, covering the area of 130,000 sq. metres. It is scheduled for launch in autumn 2019 (Zalando \& Goodman, 2018). 
Positive changes caused by Łódź joining the Chinese BRI are outshined by the fact that for many years the barrier for the development of rail freight between Poland and China has been the limited capacity of the main border crossing between Poland and Belarus (Brest-Terespol-Małaszewicze). The terminal in Małaszewicze has been recording incremental change in the number of serviced trains in recent years. In 2018, there were 2.2 thousand of them, while in 2011 - only 17. While in 2018 more than 98 percent of containers serviced in Małaszewicze were transported from or to China (Polskie porty, 2019), currently approx. 4,000 containers are reloaded there, what makes about 12 pairs of trains per day. Even though the flow of goods is not high, Małaszewicze is not able to meet the current needs of the transportation from the PRC. Moreover, the estimates indicate that in 2030 trains will transport 1 million TEUs from China to Europe, which is five times more than in 2017. For this reason, the PKP Cargo, together with the PKP Polskie Linie Kolejowe (PKP PLK), have begun relevant infrastructure investments, announcing that by 2026 the capacity of the largest dry port in Europe (that is Małaszewicze) will increase four times (to 40-50 pairs of trains per day) (Lysionok, 2019). The tender for the execution of construction works, as a part of the expansion of the terminal, was officially announced in April 2019. It includes reconstruction of the storage yard, reloading yard and tracks, construction of a parking lot for trucks, power grid, water supply and sanitary sewage system. The completion of works is planned for the end of November 2020 (PKP Cargo, 2019). However, even if after the planned modernization the capacity of the port in Małaszewicze increases four times, this may still not be enough for the further development of the NSR in Poland as China wants to double the shipment of goods every two years. The Chinese government assumes that in 2020, 5,000 trains will come to the EU. This means that the terminal in Małaszewicze will not be able to handle all of them until then. For this reason, the concept of incorporating the Biała Podlaska-Terespol line into the NSR has recently emerged, where the first modernization works are to be completed by August 2020 (Biała, 2018). 


\section{Challenges and Prospects for the Near Future}

According to the Chinese State Railways (CRC), the number of freight trains from China to Europe last year, compared to 2017, increased by 73 percent. The volume of cargo flows on the China-Europe-China route during this period amounted to 370,000 TEUs, of which 73 percent went to the Commonwealth of Independent States (CIS) countries - Russia, Kazakhstan and Belarus. According to the Chinese forecasts, for approx. 10 years, the trains will transport 1 million TEUs along the NSR (Warsewicz, 2019). Currently, Russians are trying to increase the transit of Chinese goods to the EU through the main trans-Siberian corridor which runs on the China-Moscow-Warsaw-Duisburg route. Yet, they perceive Poland as a 'bottleneck' that makes the corridor unprofitable. There are several reasons for this, main of which are: the lack of trust in Eastern contractors from European entrepreneurs, the lack of a common system of electronic exchange of shipping documentation, an inadequate infrastructure in Poland and an increasingly congested border crossing Małaszewicze-Terespol.

On the other hand, on September 15,2015, the Polish Council of Ministers adopted the National Rail Programme until 2023 (Krajowy Program Kolejowy - KPK), which defined investment tasks, including railway infrastructure managed by the PKP PLK. The main objective of the KPK envisages strengthening the role of railway transport in the integrated transport system of the country by creating a coherent and modern railway line network. Additionally, the PKP Cargo intends to be the leader of rail freight transport on the EU section of the NSR by 2023. Further investments in intermodal transport and extension of existing infrastructure are planned in Poland (i.e. terminals in Małaszewicze and Łódź), as well as further investments giving the PKP Cargo access to other markets. The acquisition of 80 percent of shares in the Slovenian company Primol-Rail may serve as a good example (Warsewicz, 2019).

Without further investment, transit from Asia may bypass Poland, though. Despite the convenient location of Małaszewicze, there are still many alternative routes, such as the one running through Kosice or the Russian ports in Ust-Luga and Kaliningrad. For the PKP PLK this means that it is necessary to develop and implement another programme, that would aim to 
repair and modernize those railway lines that are in poor technical condition and, at the same time, to take efforts to provide financial resources for the modernization of Polish rolling stock in the EU 2021-2027 perspective. Unfortunately, despite the modernization and infrastructure investments made by the company in recent years, the report of the Supreme Chamber of Control (Najwyższa Izba Kontroli - NIK) on the security situation of Polish railways in 2017 showed that almost half (about 9,000 km) railway lines still need repair or comprehensive modernization, and the technical condition of almost 83 percent of railway bridges or viaducts is alarming ((Nie)bezpieczna, 2018).

Considering these facts, subsequent investments in Polish rail infrastructure seem to be justified in every respect. The Polish freight market experiences steady growth. 2017 was very beneficial for railways. All transport parameters increased and railway carriers transported a record number of 1677.3 thousand TEUs. In comparison to 2016, this represented an increase of 16.1 percent (ORT, 2018). Considering the data for transports along the NSR only, in 2017 almost one thousand trains arrived from China to Łódź. Moreover, Chinese entrepreneurs want to further increase supplies by rail on this route, ultimately by up to 100 percent. Chinese investors are also interested in building in Łódź or its vicinity the so-called buffer warehouses for large quantities of goods regularly delivered by trains as well as halls where the equipment imported from China would be assembled from the parts in containers (Czubiński, 2017a). In turn, the terminal in Małaszewicze, which is located on the border between Poland and Belarus, served 2.2 thousand trains transported in 2018. Due to the growing flow of containers from China, by the end of 2020 it will be able to accept even 3,285 trains per year. Importantly, in August 2018 the PKP Cargo announced that by 2026 its capacity would increase even four times (Warsewicz, 2019).

\section{Conclusions}

The analysis presented in this article confirms the hypothesis that the NSR is an opportunity for a more dynamic development of railway connections in Poland. For this season, further investment in intermodal transhipment centres (e.g. in Łódź and Małaszewicze) and railway infrastructure along 
the main transport corridors running through our country (Baltic-Adriatic corridor, North Sea-Baltic Sea corridor and Amber Corridor) is still needed. In the worst case, the capacity of the main trans-Siberian corridor turns out to be limited, the transport of Chinese containers to Western Europe may even bypass Poland. As it turns out, in 2017 already 34 European cities from 12 countries had rail connections with China. Moreover, the further development of the BRI may be negatively affected by the deterioration of Sino-Polish relations, the good example of which is the unexpected and badly adopted decision of the state authorities from 2016 to suspend the tender for the sale of a plot for the construction of transhipment terminal in Łódź, as a result of which the dynamics of contacts of the entire Łódź province with partners from China has greatly suffered.

\section{ALEKSANDRA BARTOSIEWICZ, PHD}

Department of Operational Research

Faculty of Economics and Sociology

University of Lodz

39 Rewolucji 1905 r. St., 90-214 Łódź, Poland

aleksandra.bartosiewicz@uni.lodz.pl

PAULINA SZTERLIK, MSC

Department of Operational Research

Faculty of Economics and Sociology

University of Lodz

39 Rewolucji 1905 r. St., 90-214 Łódź, Poland

paulina.szterlik@uni.lodz.pl

\section{References}

Bartosiewicz, A., Szterlik, P. (2018). Nowy Jedwabny Szlak a relacje polsko-chińskie. Economics of the 21st Century, 20(4), 2-20.

Bartosiewicz, A., Szterlik, P. (2019). Łódź’s Benefits from the One Belt One Road Initiative. International Journal of Logistics Research and Applications, 22(1), 47-63. 
Bentyn, Z. (2016). Poland as a Regional Logistic Hub Serving the Development of Northern Corridor of the New Silk Route. Journal of Management, Marketing and Logistics, 3, 135-144.

Biała Podlaska: Nowy Jedwabny Szlak rośnie jak na drożḋ̇ach. (2018, June 28). Retrieved from: https://www.radio.lublin.pl/news/biala-podlaska-nowy-jedwabny-szlak -rosnie-jak-na-drozdzach.

Bocheński, T. (2018). Rozmieszczenie i charakterystyka terminali kontenerowych w Polsce oraz propozycje lokalizacji nowych obiektów. Problemy Transportu i Logistyki, $41,17-27$.

China Policy. (2017). China Going Global - between ambition and capacity. Beijing: China Policy.

CWGP-PRC. (2015). Jak ugryźć Państwo Środka? Sektor spożywczy w Chinach. Warszawa: Centrum Współpracy Gospodarczej Polska-Chiny.

Czubiński, R. (2017a, March 28). Nowy Jedwabny Szlak: Łódzkie w awangardzie. Retrieved from: http://www.rynek-kolejowy.pl/wiadomosci/nowy-jedwabny-szlak-lodzkie-w-awangardzie-80983.html.

Czubiński, R. (2017b, June 1). Łódź: Nowa bocznica na Olechowie. Pierwsza od lat. Retrieved from: https://www.rynek-kolejowy.pl/wiadomosci/lodz-nowa-bocznica-na-olechowie-pierwsza-od-lat-81962.html.

Czubiński, R. (2019, April 4). Hatrans: Przyszłość połączenia Łódź-Chengdu jest niezagrożona. Retrieved from: https://www.rynek-kolejowy.pl/wiadomosci/hatrans-przyszlosc-polaczenia-lodz--chengdu-jest-niezagrozona-91362.html.

Embassy of the RP. (2018, no date). History of the Bilateral Relations. Retrieved from: http://www.msz.gov.pl/en/p/bejrut_lb_a_en/bilateral_cooperation/history/.

Engelhardt, J. (2014). Możliwości rozwoju transportu towarowego w korytarzu zachodnim. Technika Transportu Szynowego, 1-2, 23-27.

ESPON. (2018). Comparative Analysis of Territorial Governance and Spatial Planning Systems in Europe (COMPASS). PAN Project.

Górski, J. (2016). PRC's Co-Operation with Central and Eastern European Countries in the Context of the One Belt One Road Initiative. The Case of 2016 Comprehensive Strategic Partnership between the PRC and Poland. Hong Kong: Working Paper of the Chinese University of Hong Kong.

Górski J. (2017). Central and Eastern Europe, Group 16+1 and One Belt One Road: The Case of 2016 Sino-Polish Comprehensive Strategic Partnership. Transnational Dispute Management, 14(1), 1-37.

GUS. (2017). Rocznik statystyczny handlu zagranicznego 2017. Warszawa: Główny Urząd Statystyczny.

Inicjatywa Pasa i Szlaku. (no date). Retrieved from: https://www.shiphub.pl/ inicjatywa-pasa-i-szlaku/.

Janocha, A. (2018, October 10). Powstaje Central European Logistic Hub - Nowa Dzielnica Przemysłowa $w$ Łodzi. Retrieved from: https://uml.lodz.pl/aktualnosci/artykul/ powstaje-central-european-logistic-hub-nowa-dzielnica-przemyslowa-w-lodzi-id23605/2018/10/10/.

Jaroń, M. (2018, April 5). Inwestycje w Łodzi. Gigantyczne centrum logistyczne BSH oficjalnie otwarte. Retrieved from: http://lodz.wyborcza.pl/lodz/7,35136,23230664,inwestycje-w-lodzi-gigantyczne-centrum-logistyczne-bsh-oficjalnie.html. 
Jingping, X. (2016, June 17). Full text of Chinese president's signed article on Polish newspaper. Retrieved from: http://www.xinhuanet.com/english/2016-06/17/c_135445947. htm.

Kamiński, T. (2019). What are the factors behind the successful EU-China cooperation on the subnational level? Case study of the Lodzkie region in Poland. Asia Europe Journal, 17, 227-242.

Lasoń, M. (2018). Miejsce Chińskiej Republiki Ludowej w polityce zagranicznej Polski w drugiej dekadzie XXI w. Krakowskie Studia Międzynarodowe, 2, 41-44.

Lubina, M. (2017). From Geopolitical Chance to Security Threat: Polish Public Political Discourse on the One Belt One Road Initiative. Polish Political Science Yearbook, 46, 221-238.

Luo, G. (2018, March 14). Are Chinese enterprises going global responsibly. Retrieved from: http://csr-asia.com/newsletter-are-chinese-enterprises-going-global-responsibly.

Lysionok, A. (2019, May 13). Kierunek - Małaszewicze. Retrieved from: https://www. $\log 24 . p l /$ artykuly/kierunek-malaszewicze,9750.

Łopacińska, K. (2017). One Belt One Road jako wyraz globalnej ekspansji Chin. Marketing i Zarzadzanie, 1, 29-38.

Marszałek-Kawa, J. (ed.). (2014). Globalna potęga Chin. Czynniki i perspektywy. Toruń: Wydawnictwo Adam Marszałek.

Marszałek-Kawa, J., Dmochowski, T. (eds.). (2018). Rozważania o kierunkach współczesnej polityki Chin. Toruń, Wydawnictwo Adam Marszałek.

Motowidlak, U., Kujawa, M. (2018). Transport towarów w projekcie One Belt and One Road jako komponent globalnego łańcucha dostaw. Łódź: Wydawnictwo Uniwersytetu Łódzkiego.

MIiB. (2015). Krajowy Program Kolejowy do 2023 roku. Warszawa: Ministerstwo Infrastruktury i Budownictwa.

MSZ (2016). Strategia Polskiej Polityki Zagranicznej 2017-2021. Warszawa: Ministerstwo Spraw Zagranicznych.

MTBiGM. (2012). Strategia Rozwoju Transportu do 2020 roku (z perspektywą do 2030 roku). Warszawa: Ministerstwo Transportu, Budownictwa i Gospodarki Morskiej.

(Nie)bezpieczna kolej. NIK informuje: nie jest dobrze. (2018, March 1). Retrieved from: https://portalkomunalny.pl/niebezpieczna-kolej-nik-informuje-nie-jest-dobrze-370692/.

Operatorzy połaczeń kolejowych na trasie Chiny-Polska. (2019, no date). Retrieved from: https://www.shiphub.pl/transport-kolejowy-operatorzy-polaczen/.

ORT. (2018). Przewozy intermodalne w 2017 roku. Podsumowanie Prezesa UTK. Warszawa: Urząd Transportu Kolejowego.

PKP. (2015). Aktualne i planowane na najbliższe lata inwestycje infrastrukturalne PKP PLK S.A. stużace rozwojowi transportu intermodalnego. Warszawa: PKP Polskie Linie Kolejowe S.A.

PKP Cargo inwestuje w rozwój Nowego Jedwabnego Szlaku. (2019, April 16). Retrieved from: http://300gospodarka.pl/news/2019/04/16/pkp-cargo-inwestuje-w-rozwoj -nowego-jedwabnego-szlaku/. 
Przywódcy Polski i Chin na forum o Nowym Jedwabnym Szlaku. (2016, June 20). Retrieved from: https://www.pap.pl/aktualnosci/news\%2C545804\%2Cprzywodcy-polski-i-chin-na-forum-o-nowym-jedwabnym-szlaku.html.

Polskie firmy zyskały sprzymierzeńca na Nowym Jedwabnym Szlaku. (2018, November 22). Retrieved from: https://www.tvp.info/40084233/polskie-firmy-zyskaly-sprzy mierzenca-na-nowym-jedwabnym-szlaku.

Polskie porty i Małaszewicze są kluczowe dla przewozów intermodalnych Nowym Jedwabnym Szlakiem. (2019, April 11).Retrieved from:https://strefabiznesu.pl/polskie-porty-i-malaszewicze-sa-kluczowe-dla-przewozow-intermodalnych-nowym-jedwabnym-szlakiem/ ar/c3-14042379.

Regulation (EU) No. 1315/2013 of the European Parliament and of the Council of 11 December 2013 on Union guidelines for the development of the trans-European transport network and repealing Decision No 661/2010/EU.

Warsewicz: Terminal w Małaszewiczach zwiększy przepustowość do 3285 pociagów. (2019, April 12). Retrieved from: https://www.rynek-kolejowy.pl/wiadomosci/nowy-jedwabny-szlak--szansa-dla-kolejowych-przewozow-towarow-w-polsce-91468. html.

Są tereny, można budować w Łodzi centrum logistyczne. (2017, February 24). Retrieved from: https://www.nakolei.pl/sa-tereny-mozna-budowac-lodzi-centrum-logistyczne/.

Sino-Polish Strategic Partnership. (2011, December 20). Retrieved from: http://www.prezydent.pl/archiwum-bronislawa-komorowskiego/aktualnosci/wizyty-zagraniczne/ art,140,polsko-chinskie-partnerstwo-strategiczne.html.

Skorupska, A., Szczudlik, J. (ed.) (2019). Regionalny wymiar stosunków Unii Europejskiej $z$ Chinami. Warszawa: Polski Instytut Spraw Międzynarodowych.

Sulmicki, J. (2018). Chiny tworzą nowy ład globalny. Zeszyty Naukowe Wyższej Szkoły Ekonomii i Informatyki, 16, 184.

Szczudlik-Tatar, J. (2015). Poland-China Relations: Forging a Strategic Partnership? In M. Huotari, M. Otero-Iglesias, J. Seaman, A. Ekman (eds). Mapping Europe-China Relations. A Bottom-Up Approach (56-61). ETNC Report.

Szczudlik-Tatar, J. (2016). Poland on the Silk Road in Central Europe: To Become a Hub of Hubs? In F-P. van der Putten, J. Seaman, M. Huotari, A. Ekman, M. Otero-Iglesias (eds). Europe and China's New Silk Roads (45-48). ETNC Report.

Tuszyński, R. (2014). Stosunki polsko-chińskie. INFOS. Biuro Analiz Sejmowych, 15, 1. Walkowski, M. (2017). Chiński model rozwoju społeczno-gospodarczego i jego potencjalna adaptacja w Europie. Przeglad Strategiczny, 10, 335-365.

White Paper. Roadmap to a Single European Transport Area - Towards a competitive and resource efficient transport system (COM/2011/0144 final).

Zalando \& Goodman świętują zawieszenie wiechy w podłódzkim Głuchowie (gm. Tuszyn). (2018, April 18). Retrieved from: https://www.tulodz.pl/wiadomosci,zalando-goodman-swietuja-zawieszenie-wiechy-w-podlodzkim-gluchowie-gm-tuszyn-wideo-foto,wia5-3273-7942.html. 